\title{
ORCHIDS IN A CHANGING CLIMATE
}

\author{
Phillip CRIBB
}

Royal Botanic Gardens, Kew, Richmond, Surrey TW9 3AB, United Kingdom

\begin{abstract}
AвSTRACT. Orchids have a long and distinguished recorded history, traceable back to the ancient Greeks. For two millennia or more, our knowledge of orchids remained sketchy, mainly because the main centers of learning were in temperate regions with poor orchid floras. Beginning with the Renaissance, knowledge increased more rapidly. Almost half a century ago, Professor William Stearn outlined this progress in his landmark lecture at the Third World Orchid Conference in London. However, knowledge has moved rapidly since then. In this lecture, I would like to update Stearn's story. The availability of new technologies has produced unprecedented advances in many aspects of orchids from our understanding of the origins of orchids to dealing with threats to their future survival. The world has become increasingly aware of issues such as climate change that are likely to have a dramatic effect on the world's orchids. I have identified five developments that have underpinned these new insights since Stearn's lecture was delivered: $\bullet$ Cloning orchids; $\bullet$ Computing power; $\bullet$ DNA analysis; $\bullet$ The fossil orchid; $\bullet$ Conservation techniques.
\end{abstract}

Resumen. Las orquídeas gozan de una historia registrada larga y distinguida, que puede ser rastreada a los antiguos griegos. Durante dos milenios o más, nuestro conocimiento relativo a las orquídeas se ha mantenido superficial, básicamente debido a que los centros de conocimientos se encontraban en regiones templadas con una pobre flora de orquídeas. Al inicio del Renacimiento, el conocimiento aumentó en forma más rápida. Hace casi medio siglo, el profesor William Stearn delineó este progreso en su conferencia que constituye un hito, presentada en la Tercera Conferencia Mundial de Orquídeas en Londres. Sin embargo, el conocimiento se ha desplazado en forma vertiginosa desde ese momento, y ha identificado cinco desarrollos principales que han dado sustento a estos nuevos discernimientos - clonación de orquídeas, potencia de computación, análisis de ADN, la orquídea fósil y técnicas de conservación - que ha generado impactos principales en la ciencia de las orquídeas, horticultura, y conservación. La disponibilidad de nuevas tecnologías y descubrimientos han generado avances sin precedentes en muchos aspectos relativos a las orquídeas, desde nuestra comprensión relativa a los orígenes de orquídeas al manejo de las amenazas para su supervivencia futura. El mundo se ha vuelto crecientemente consciente de temas como el cambio climático que con gran probabilidad van a tener un efecto dramático sobre las orquídeas del mundo.

KEY WORDS: Orchids, cloning, computing, DNA analysis, fossil orchid, conservation techniques

Almost half a century ago, the late William Stearn (1960), addressing the 3rd World Orchid Conference in London, presented what he considered to be 10 landmarks in the knowledge of orchids, a family which he labeled as the most promiscuous of all plants based on the ability of often unrelated species to produce successful hybrids. His landmarks were as follows:

1. The first naming of orchids by ancient Greeks and Romans dating from before the time of Christ.

2. The first recognition of orchids as a special group in late 17 th century.

3. The introduction and first flowering tropical orchids to Europe in the late 17th and early 18th centuries.

4. The application of binomial nomenclature to orchids by Linnaeus in 1753 .

5. The change in method for heating greenhouses from dry to wet heat, stimulating their introduction and the publication of finely illustrated books about them in the 19th century.

6. The elucidation of the pollination mechanisms of orchids by Darwin.

7. The raising and flowering of the first artificial hybrid in 1861 . 
8. The raising and flowering of the first artificial intergeneric hybrid in 1868 .

9. The discovery of the orchid mycorrhizal association.

10. The raising of the first orchid seedlings asymbiotically in the early 20th century.

In this lecture I would like to bring Stearn's landmarks up to date by suggesting five new landmarks since his comprehensive historical survey of the orchids. It is perhaps symptomatic of the speed of change over the past few years that I could easily list many more. The new major landmarks I would submit are as follows:

- Micropropagation: The cloning of orchids, which has made them available to all, leading to a truly worldwide trade in orchid hybrids.

- Computing: The application of computing power for orchids and the publication of the first world checklist of orchids on the internet.

- DNA analysis: The application of DNA analysis to orchid systematic problems, including estimating the age of the family. Publication of Genera Orchidacearum, introducing a new system of classification for the orchids, incorporating molecular and morphological data.

- The fossil record: The first irrefutable orchid fossil, allowing dating of the origins of the family.

- Conservation: A new awareness of the fragility of orchids and their habitats and the need for their conservation both in situ and ex situ, a situation made more urgent by the threat of climate change.

I will deal with each in turn, some in more detail than others. Some of the landmarks have produced wholly positive outcomes, but others have been met with controversy.

\section{Micropropagation}

Cloning orchids by meristem culture is so commonplace nowadays that we tend to forget what a revolution it has nurtured. Orchids have been transformed from the playthings of the rich to an everyday commodity, admittedly a fashionable one. Every department store and greengrocer now sells cutflower and pot-plant orchids, and prices have tumbled. Consequently, the public's appreciation of orchids has improved, and the status of the orchid as the most charismatic of plants has been bolstered.

Not all the consequences have been beneficial to the core orchid community. Orchids are now commonly sold without their correct name. Plants are marketed as 'moth orchid', 'windowsill orchid' or other trivial names. When a generic name is given, it is often without a grex or clonal name. The introduction of plant patents some years ago has further confused buyers but benefited breeders. Mutations can also arise in culture, requiring new cultivar names to be applied to those clones that differ from the parental plant. The problem does not, of course, affect the buyer whose interest in the plant is purely decorative, but good clones have been multiplied and the offspring used to produce new hybrids. If the parental names are absent or incorrect, the offspring cannot be named according to longstanding rules for naming of cultivated plants (Brickell, 2004). It could be argued that names are unimportant, but, as I will elaborate upon later, they form the backbone of access to knowledge about orchids, indeed about all organisms.

\section{Computing}

It is perhaps self-evident that computers have changed the world. I would like to consider how they have changed orchid science and culture through a few examples. The number of websites now devoted to orchids is immense. You can buy orchids over the internet, find out how to identify them, name them, grow them, propagate them, and conserve them all at the click of a button. Input the word 'orchid' into a websearch provider, and pages of addresses are revealed. Some sites, such as Wikipedia, have developed a holistic approach, but the quality of information on orchids in them is variable. Websites run by the American Orchid Society (www.aos.org) and Royal Horticultural Society (http://www.rhs.org.uk/plants/ plant_groups/orchids.asp) are authoritative and contain high quality information and images on many aspects of orchids. A number of societies and orchid groups also publish their journals and newsletters on the web.

Original high-quality information on orchids can also be sought on a number of other websites. I would like to feature two here, the first of which is the World Monocot Checklist (http://www.kew.org/wcsp/ monocots) based at the Royal Botanic Gardens, Kew. It is regularly updated through an international network 
of orchid specialists who provide comments and queries on the taxonomy used by its compiler, Rafael Govaerts. Why is a checklist of orchids important? We cannot communicate satisfactorily about anything unless we can give it a 'handle'. For living organisms, their scientific names provide the handles for knowledge to be shared. Orchid names and their synonyms provide the only reliable spine to access information on orchids.

The second website I would recommend and use regularly is that being developed by the Jany Renz Foundation at the University of Basel (http://orchid. unibas.ch/site.herbarium. php). Features of this website include thousands of images of orchids (photographs, illustrations from all of the historically important orchid books, and herbarium specimens) and access to the most complete bibliography of the orchids (BibliOrchidea). A searchable biographic database of all of the most significant orchid personalities is another useful feature.

\section{DNA analysis}

For the scientist, one of the most significant features of the computer is its ability to analyze large data sets, and this brings us to the next landmark event, the analysis of orchid DNA. DNA data sets can be large, especially when several genetic sequences are analyzed at once. It would not be an exaggeration to state that the ability to sequence the DNA of orchids has revolutionized our understanding of the family. The work of Mark Chase and his many collaborators has resulted in the evolutionary history of orchids becoming the best understood of any family of flowering plants. This is in marked contrast to the position just 25 years ago when few scientists were attracted to the family, which was considered to be too large and too horticultural to be of interest. In short, most scientists preferred to work on smaller families where their results were less likely to be the subject of horticultural dispute and infighting. This situation has fortunately changed dramatically. Chase's work has attracted the attention, interest, and collaboration of some of the brightest young scientists. Their work has led to a better understanding of orchids as a family, the relations of its constituent parts, and the classification of orchids.

We now know that:

1) The closest relatives of orchids are a small number of mainly Southern Hemisphere families of asparagoid monocots (Table 1), of which the best known is Hypoxis, a terrestrial genus with plicate leaves and yellow stellate flowers.

2) Orchids are a monophyletic family that includes apostasioids, cypripedioids, and the rest of the orchids as defined by Willis (1973). Both apostasioids and cypripedioids have been recently considered discrete families by some authors (e.g. Rasmussen, 1985).

3) Vanilla and its relatives (16 genera in all) are an ancient lineage worthy of subfamilial status.

4) Spiranthoid orchids are not worthy of subfamilial status and comprise a group within the orchidoids.

5) The circumscriptions of many long-accepted genera, e.g. Cattleya, Laelia, Masdevallia, and Oncidium have been greatly amended. Others, notably Odontoglossum, do not warrant recognition at all.

6) Floral features have often misled taxonomists, whereas vegetative characters can be more conservative and better reflect relationships, an idea first proposed by Pfitzer over a century ago.

These ideas are currently being assembled in the monumental Genera Orchidacearum (Pridgeon et al., 1999, 2001, 2003, 2005), one volume of which still remains. This work has involved close to 100 collaborators worldwide. It is not, and was never meant to be, the final word on orchids and their classification. However, it does summarize our current knowledge of the phylogeny (evolutionary relationships), classification, and many other aspects of the family.

DNA has also been used at the species and infraspecific levels. One interesting project with wider

TABLE 1. Families of Asparagales allied to Orchidaceae (Chase, 2001).

\begin{tabular}{l|l}
\multicolumn{1}{c|}{ Family } & \multicolumn{1}{c}{ Distribution } \\
\hline Asteliaceae & Australia \\
\hline Boryaceae & Australia \\
\hline Doryanthaceae & Australia \\
\hline Blandfordiaceae & Australia \\
\hline Lananaceae & South Africa, South America \\
\hline Hypoxidaceae & Africa, South America \\
\hline Tecophilaceae & South Africa, South America \\
\hline Ixioliriaceae & Asia \\
\hline
\end{tabular}


implications is the Darwin Initiative-sponsored project in Costa Rica, run by Vincent Savolainen and Jorge Warner, which is seeking to barcode the 1300 or so orchid species found in the country. The consequences of this for an understanding of species delimitation, rapid identification, and conservation have only begun to be considered.

In Australia the use of DNA sequencing for orchid conservation is being rapidly developed by Kingsley Dixon and his team at King's Park, Perth, Australia. Recent work has indicated that the two surviving populations of the Western Australian underground orchid (Rhizanthella gardneri) might represent two closely allied but distinct species (Kingsley Dixon, personal communication). Cryptic species have also been identified using DNA sequencing in other Australian orchid genera, notably Drakaea (Hopper and Brown, 2007) and Chiloglottis (Florian Schiestl, personal communication).

Conversely, DNA analysis of the 259 currently accepted European Ophrys species has revealed only 10 distinct groups separable by their DNA. It seems probable that many new species are described where there are many botanists rather than where biodiversity is greatest (Dion Devey, personal communication).

The other major issue with the new classification is the changing of generic concepts from long-accepted ones. This affects a number of the most important genera in horticulture, including Cattleya, Laelia, Masdevallia, Odontoglossum, and Oncidium. In the era before DNA analysis, the orchid registrar used a system of horticultural equivalents to conserve well-established generic and specific names for the orchid hybrid register. These names survived for decades in horticultural use when the botanists had long since consigned them to synonymy. For the past few years or so, the system has been abandoned, and the currently accepted scientific names have been used by the registrar, leading to many changes not only in specific names but also in hybrid generic (nothogeneric) names. The rationale for this is that the new DNA-based classification better reflects true affinities and breeding behavior and that the use of computers allows the ready retrieval of both the old and new names, obviating the need for horticultural equivalents. For the most part, the Registrar has made changes only where the scientific evidence is sound and a degree of consensus among his advisors has been achieved. However, phylogenies are subject to different interpretation, so there is plenty of room for disagreement. My own opinion is that the present system of nothogeneric recognition is no longer useful in orchid hybridizing and is often confusing. Most nothogeneric names have little information content, particularly those for trigeneric hybrids and above which use a personal surname followed by -ara. I believe that a new system that recognizes the breeding groups is necessary to prevent confusion. Such a system will simplify registration and label writing as long as grex names are not repeated within a breeding group (which they mostly are not!). Mark Chase, Sarah Thomas, and I spelled out the need for a new system some years ago (Cribb et al., 1999).

\section{The orchid fossil record}

The discovery of the first irrefutable orchid fossil, Meliorchis caribea, was announced by Ramirez et al. (2007) in the journal Nature. It comprised an orchid pollinarium on the back of a bee, the extinct Proplebeia dominicana, set in 15-20 million-year-old Miocene amber from the Dominican Republic. The discovery of the fossil represents a significant step forward in our knowledge of the antiquity of the orchids. The pollinarium can be safely assigned to a species of the terrestrial Goodyerinae, possibly Kreodanthus or Microchilus, probably no longer extant but having living relatives. The significance of this discovery confirms that the orchids are an ancient group, a view developed from the DNA work where the divergence of particular orchid taxa can be estimated from the rate at which nucleotide changes accumulate in DNA sequences. Chase (2001) suggested that the orchid lineage might be up to 90 million years old, in contrast to earlier opinions that the family evolved recently (Schmid \& Schmid, 1977; Labandeira, 1998). Ramirez et al. (2007) suggested a date of about 76-84 million years ago in the late Cretaceous for the emergence of the family. Both support a pattern of an ancient family that contains five surviving lineages of which three the apostasioids, cypripedioids, and vanilloids — are now represented by relatively few surviving species. In contrast, the predominantly terrestrial orchidoids and the mainly epiphytic epidendroids have been extremely successful with a rapid adaptive radiation in relatively 
recent times, particularly since the end of the last glaciation in the tropical mountain chains, such as the Andes, Central American highlands, the Himalayas, and the mountains of the Malay Archipelago.

\section{Conservation}

The orchid world can be proud of its considerable effort towards orchid conservation, particularly in the last 20 years. It has been aware of the rarity of many species, especially some of the showiest orchids, for over a century. In the $1880 \mathrm{~s}, \mathrm{H}$. G. Reichenbach expressed concern at the scale of orchid collection for the nursery trade. Over the past 25 years, the rapidly increasing rate at which orchids and their habitats have disappeared has added impetus to a number of initiatives by the orchid community that have begun to address these serious issues. The causes are well documented, but the initiatives are perhaps less well appreciated by the public at large.

The Orchid Specialist Group, an arm of IUCN (The World Conservation Union) Species Survival Commission, has been particularly active and successful in stimulating research and projects on endangered orchids. The OSG comprises some 200 orchid scientists and horticulturists worldwide. Under the chairmanship of Michael Fay of the Royal Botanic Gardens, Kew, it has sponsored three successful International Orchid Conservation Conferences, in Australia, USA, and Costa Rica. The fourth is due in 2011 and will be held in the Czech Republic. Further information can be gained from the OSG website (http://www.orchidconservation.org/osg). The OSG also produces an electronic newsletter.

Perhaps the main result of the work of the OSG has been to bring together current ideas and methodologies for orchid conservation, both in situ and ex situ, and emphasize the need for the integration of both approaches to attempts to conserve orchids. One of the main products of the First Conference in Perth, Australia, was a techniques manual entitled Orchid Conservation (Dixon et al., 2003).

In 2003, the OSG established a charitable foundation named Orchid Conservation International (http://www. orchidconservation.org) to support its work and that of orchid conservation projects worldwide. This is one of several successful grant-giving bodies, ranging from the American Orchid Society and Australian Orchid
Foundation to the San Diego Orchid Society and 1\% for Orchid Conservation.

On a broader scale, I would like to mention the recent Darwin Initiative project to set up a world network of orchid species seed-banks. The first two workshops in Chengdu, China, and Quito, Ecuador, attracted a broad-based response. The project, Orchid Seed Stores for Sustainable Use, aims to establish protocols for orchid seed collection and storage based upon sound scientific evidence and set up a network of active orchid seed-banks in orchid-rich countries. [See paper by Seaton and Pritchard in this volume. - ed.]

Orchids face increasing threats to their existence, not only the obvious ones posed by increasing human population, logging, mining, and exploitation. Climate change will undoubtedly affect orchids. David Roberts (personal communication) has shown that orchid flowering times in the UK are increasingly out of synchronization with the emergence of their pollinating insects. Many naturalists have noted the decrease and disappearance of orchids from local habitats that appear to be still suitable. Was this triggered by climate change? It may well have been, because orchids have complex interactions with their environment that can easily be upset, from the fungi and bacteria that control germination and early growth to the pollinators that are necessary to produce viable seed. Change in one factor can wreck such sensitive interactions, and all the evidence indicates that climate change will be a powerful driver of irreversible change (Intergovernmental Panel on Climate Change Report IPCC, 2007).

\section{Conclusions}

Rapid development of techniques over the past 50 years has meant that our knowledge of orchids has increased at a rate far greater than at any time in the past. New techniques have brought new and exciting talent into orchids in the fields of science, horticulture, and conservation. Not all of the developments have been welcome in the orchid community, particularly those that require the relearning of plant relationships, classification, and names. Old ideas and concepts are being ditched and new ones proposed with frightening speed. With sound scientific information and analysis, we can take some new concepts happily on board, whereas for others the evidence remains shaky. The 
science of orchid conservation can also provide a more secure future for orchids if is it is applied more widely. We have the knowledge and technology to conserve orchids, but often the limiting factor is funding. The new Darwin Initiative on global seed-banking of orchids is one that is good news for orchids and orchid growers, providing access to plants that can no longer be found in the wild or are protected and cannot be taken from it. Overshadowing all this, however, is the unknown effect of global climate change predicted by the recent report from a UN panel of experts. Will orchid habitats survive the upheavals that have been predicted? I do not know, but I would love to be around to hear the update on orchid landmarks in 50 years.

\section{LiTERATURE CITED}

Brickell, C. D. 2004. International code of nomenclature for cultivated plants. IAPT, Vienna, Austria.

Chase, M. W. 2001. The origin and biogeography of Orchidaceae. Pp. 1-5 in: A.M. Pridgeon, P. J. Cribb, M. W. Chase \& F. N. Rasmussen (eds.) Genera orchidacearum, Volume 2. Orchidoideae (Part one). Oxford University Press, UK.

Cribb, P. J., Chase, M. W., and Thomas, S. 1999. Orchid hybrid generic names - time for a change? Pp. 395-396 in: S. Andrews, A. Leslie, and C. Alexander (eds.). Taxonomy of cultivated plants. Royal Botanic Gardens, Kew, UK.

Dixon, K. W., S. P. Kell, R. L. Barrett \& P. J. Cribb (ed.). 2003. Orchid conservation. Natural History Publications, Kota Kinabalu, Sabah, Malaysia.

Intergovernmental Panel on Climate Change Report 4. 2007. http://www.ipcc.ch/

Hopper, S. D. \& A. P. Brown. 2007. A revision of Australia's hammer orchids (Drakaea: Orchidaceae), with some field data on species-specific sexually deceived wasp pollinators. Austral. Syst. Bot. 20: 252-285.

Labandeira, C. C. 1999. Paleobiology: how old is the flower and the fly? Science 280: 57-59.

Pridgeon, A. M., P. J. Cribb, M. W. Chase \& F. N. Rasmussen. 1999. Genera orchidacearum, Volume 1. General introduction, Apostasioideae, Cypripedioideae. Oxford University Press, UK.

Pridgeon, A. M., P. J. Cribb, M. W. Chase \& F. N. Rasmussen. 2001. Genera orchidacearum, Volume 2. Orchidoideae (Part one). Oxford University Press, UK.

Pridgeon, A. M., P. J. Cribb, M. W. Chase \& F. N. Rasmussen. 2003. Genera orchidacearum, Volume 3. Orchidoideae (Part two), Vanilloideae. Oxford University Press, UK.

Pridgeon, A. M., P. J. Cribb, M. W. Chase \& F. N. Rasmussen. 2005. Genera orchidacearum, Volume 4. Epidendroideae (Part one). Oxford University Press, UK.

Pridgeon, A. M., P. J. Cribb, M. W. Chase \& F. N. Rasmussen. 2009. Genera orchidacearum, Volume 5. Epidendroideae (Part two). Oxford University Press, UK.

Ramirez, S. R., B. Gravendeel, R. B. Singer, C. R. Marshall, $\&$ N. E. Pierce. 2007. Dating the origin of the Orchidaceae from a fossil orchid with its pollinator. Nature 448: 10421045 .

Rasmussen, F. N. 1985. Orchidaceae. Pp. 249-274 in: R. M. T. Dahlgren, H. T. Clifford, and P. F. Yeo (eds). The families of monocotyledons: structure, evolution and taxonomy. Springer Verlag, Berlin, Germany.

Schmid, R. and Schmid, M. J. 1977. Pp. 17-45 in: J. Arditti (ed.). Orchid biology: reviews and perspectives 1. Cornell University Press, Ithaca, New York, USA.

Stearn, W. T. 1960. Two thousand years of orchidology. Pp. 26-41 in: P. M. Synge (ed.). Proceedings of the 3rd World Orchid Conference. Royal Horticultural Society, London, UK.

Willis, J. C. 1973. A dictionary of the flowering plants and ferns. 8th ed. Cambridge University Press, UK. 